\title{
Keeping record of the postoperative nursing care of patients
}

\author{
$\mathrm{L}$ Roets, PhD, University of the Free State
}

MC Aucamp, B Soc.Sc (Nursing), University of the Free State

$\mathrm{H}$ de Beer, BSoc.Sc (Nursing), University of the Free State

M Niemand, B Soc.Sc (Nursing), University of the Free State

\section{Summary}

The aim of this research project was to evaluate the recordkeeping of postoperative nursing care. A total of 186 randomly selected patient records were evaluated in terms of a checklist that included the most important parameters for postoperative nursing care. All the patients underwent operations under general anaesthetic in one month in a Level 3 hospital and were transferred to general wards after the operations.

The data collected was analysed by means of frequencies. One finding was that the neurological status of most patients was assessed but that little attention was paid in the patient records to emotional status and physical comfort. The respiratory and circulatory status of the patients and their fluid balance were inadequately recorded. The patients were well monitored for signs of external haemorrhage, but in most cases haemorrhage was checked only once, on return from the theatre. Although the patients' pain experience were well-monitored, follow-up actions after the administration of pharmacological agents was poor. The surgical intervention was fully described and, generally speaking, the records were complete and legible, but the signatures and ranks of the nurses were illegible. Allergies were indicated in the most important records.

The researchers recommend that a comprehensive and easily usable documentation form be used in postoperative nursing care. Such a form would serve as a checklist and could ensure to a large degree that attention is given to the most important postoperative parameters. Errors and negligence could also be reduced by this means.

\section{Opsomming}

Die doel van hierdie navorsingsprojek is om die rekordhouding van postoperatiewe verpleegsorg te evalueer. 'n Totaal van 186 ewekansig geselekteerde pasiëntrekords is aan die hand van 'n kontrolelys wat die belangrikste parameters vir postoperatiewe verpleegsorg insluit, geëvalueer. Die pasiënte het almal gedurende een maand operasies in ' $n$ Vlak 3-hospitaal onder algemene narkose ondergaan en is na afloop van die operasies na algemene sale teruggeplaas.

Die data wat ingesamel is, is deur middel van frekwensies geanaliseer. Daar is bevind dat die meeste pasiënte se neurologiese status beraam word maar dat min aandag in die pasiëntrekords aan emosionele status en fisieke gemak gegee word. Die pasiënte se respiratoriese en sirkulatoriese status asook vloeistofbalans word onvoldoende hanteer. Die pasiënte word goed vir tekens van uitwendige bloeding gemonitor, maar in die meeste gevalle word bloeding slegs eenmalig met terugontvangs vanaf die teater gekontroleer. Voorts word die pasiënte se pynervaring goed gemonitor maar opvolgaksies na die toediening van farmakologiese middels is swak. Die operatiewe ingreep word volledig beskryf, die rekords is oor die algemeen volledig en leesbaar maar verpleegkundiges se handtekeninge en range is onleesbaar. Allergieë word in die belangrikste rekords aangetoon.

Daar word aanbeveel dat ' $n$ omvattende en maklik bruikbare dokumentasievorm in postoperatiewe verpleegsorg gebruik word. Sodanige vorm sal as 'n kontrolelys dien en kan in ' $n$ groot mate verseker dat aandag aan die belangrikste postoperatiewe parameters gegee word. Foute en nalatigheid kan ook op hierdie wyse verminder word.

\section{Introduction and problem statement}

The aim of the postoperative phase of nursing care is to exclude complications and to help the patient to return to an optimum level of functioning as soon as possible (Phipps, Long, Woods \& Cassmeyer, 1999:493).
The first few hours after a patient has been returned to the general ward are important because it is in this period that changes in the condition of a patient most easily occur (Phipps et al., 1999:500).

As important as it is to make a full assessment of the patient during this few hours, it is for the nurse to record her findings carefully in the patient's report, which is a legal docu- 
ment (Breslow, Miller \& Rogers, 1990:52; Chappel, 1997:50; Kaempf \& Goralski, 1996:31). In a number of professional hearings recently conducted by the South African Nursing Council, the importance of record-keeping was stressed once again. The basic rule remains valid: what is not written down, has not been done (Herbst, 1997:39-42).

When a patient's records are audited there should therefore be a clear indication of the parameters the nurse used to assess the patient and to adapt her nursing care accordingly (Suddarth, 1994:56-58). Record-keeping according to the assessment of a patient therefore is crucial (Verschoor, Fick, Jansen \& Viljoen, 1996:13-14).

Various sources (Phipps et al., 1999:527-549; Suddarth, 1994:56-58) agree that the most basic areas of patient assessment and therefore record-keeping after surgery are the following:

\begin{tabular}{ll} 
- & Neurological status \\
- & Respiratory status \\
- & Circulatory status \\
- & Urinary status \\
- & Prainage systems \\
- & Pressical comfort \\
\hline
\end{tabular}

These are the minimum parameters that a reasonable nurse should take into account in the assessment of a postoperative patient and thus the things to record. Depending on the type of operation there will, naturally, be additional parameters to be monitored and nursing actions to be performed and recorded.

There are no set rules and regulations that lay down which parameters a nurse must use for the postoperative assessment and recording of patients. She must use her professional knowledge to assess the patient and, in the process, may easily omit the evaluation and recording of a particular parameter. Such an omission can have serious legal implications should the patient suffer harm and lay a charge of omission or negligence against the nurse or health care institution. The question that may therefore rightly be posed is:

\section{Are adequate records kept in postoperative nursing care?}

\section{Aim}

The aim of this project was to evaluate the record-keeping of postoperative nursing care in general wards for the first eight hours after the patients returned from surgery.

\section{Objectives}

The objectives were to: identify the various parameters used for postoperative nursing care;

identify the nursing actions implemented in terms of the assessment of the patient;

evaluate the parameters and nursing actions by means of a checklist;

identify the problem areas that could have legal implications;

set guidelines for the minimum requirements for post operative assessment and recording.

\section{Research design}

A quantitative descriptive design is appropriate for this study as according to Neuman (1997:19) descriptive studies should:

- give an accurate profile of the study design

- describe the process

- $\quad$ give percentages and numeric value

- place a situation in context and

- $\quad$ help to classify categories

The study is descriptive as data about a specific phenomenon (record-keeping of post-operative nursing assessment) was collected and a description is given of the phenomenon as it was found (Burns \& Grove, 2001:52).

\section{Method}

A retrospective audit was carried out on the records of patient assessment and nursing care for the first eight hours after the patients were received back in the ward postoperatively. The progress reports, observation charts, fluid balance charts and nursing care plans of selected patients were studied.

A checklist compiled after a thorough literature analyses, was used that contained the minimum parameters for effective postoperative patient assessment as recommended in a number of sources in the literature (Phipps et al., 1999:527-549; Suddarth, 1994:56-58; Pollock, 1991:23; van der Merwe \& Shipton, 1990:1221-1227; Kaempf \& Goralski, 1996:31).

\section{Sample selection}

The patient records of a tertiary hospital were used. This specific hospital was used because:

students are placed there and therefore a reasonable standard assessment and recording should be maintained; the nursing care should be representative of the standard in other hospitals in the region.

The records of all the general wards in the hospital where operation cases are nursed were evaluated. In order to compile a representative sample all the operation cases in May were counted, after which the following inclusion and exclusion criteria were used:

only the records of patients who received a general anaesthetic were used;

only the records of patients who were transferred directly from the recovery room to a general ward were used (for instance, patients who had undergone thoracic surgery or cerebral interventions and were trans- 
ferred to intensive care units, were not considered).

In this way 540 of a possible 607 records were selected. On the recommendation of the Department of Biostatistics (University of the Free State) a sample of 200 was decided upon, as this would enhance the validity and reliability of the study. In order to provide for patient records that could perhaps not be traced and for patients who might unexpectedly be transferred to intensive care units postoperatively, it was decided to select 250 patient records.

A systematic random selection of the sample was performed. The first patient number on the selected list was drawn after which the following second and alternate third patient numbers were drawn until a total of 243 patient numbers had been selected.
Ten records were randomly selected in April. They were evaluated by means of the checklist and several changes and additions were made in the process. A question about allergies was added and the pilot study also found that patient names and numbers were not complete on the records. This aspect was also included on the checklist. Each of the three researchers evaluated the ten records separately after which they reached consensus on the clarity, completeness and interpretation of the checklist.

The three researchers were together for the major part of the data collection in the records department. They consulted one another throughout about filling in the checklist if there were doubts about any aspect. This promoted the validity and reliability of the data collection.

\section{Figure 1: Nature and extent of evaluated operation cases}

\section{TYPES OF OPERATION CASES}

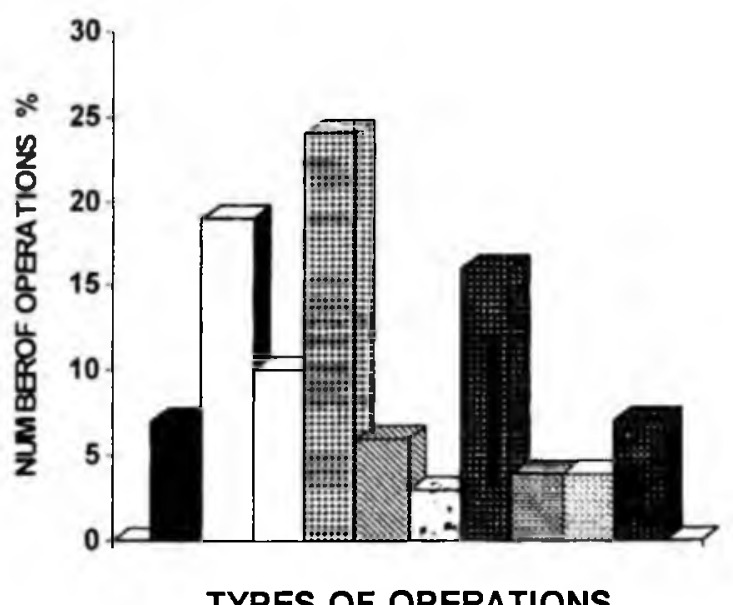

- Skull and vertebral column

$(n=12)$

$\square$ Gynae cological $(n=36)$

$\square$ Abdominal $(n=19)$

[or, nose and throat $(n=45)$

Operatioins to $\lim b s(n=11)$

$\square$ Thoracic $(n=4)$

- Urological $(n=31)$

Skin grafts and flaps $(n=7)$

Breast ope rations $(n=7)$

- Other $(n=14)$
The records of the selected patient numbers were then drawn from the record department of the hospital and those that still did not meet the inclusion criteria had a note made opposite the number and that record was not included. In the end only 186 patient records were suitable for the research purpose.

\section{Validity and reliability}

A retrospective audit was decided upon, as this would eliminate the possibility of the record-keeping of the nursing staff being influenced by the study. (To enhance the validity and reliability of the checklist it was submitted to a domain expert for evaluation and a pilot study was carried out).

\section{Ethical aspects}

Consent for the research was obtained from the Ethics Committee and the Faculty of Health Sciences of the UFS as well as the Chief Executive Officer of the hospital in question. The information about the patients, staff and the particular wards was regarded as confidential and no names of either a patient, a ward or a staff member appeared on the checklists.

\section{Data analysis}

The Department of Biostatistics, UFS processed the checklists by computer and compiled tables and percentages in terms of which the data could be interpreted. 


\section{Findings}

\section{Biographical data}

The checklist which made up the basis of the research, tested whether the patient records studied paid attention to all the most important parameters of postoperative nursing care, i.e. neurological and emotional status, physical comfort, respiratory and circulatory status, postoperative pain and fluid balance (Phipps et al., 1999:527-549; Suddarth, 1994:56-58).

The completeness and legibility of the records, and the degree to which they met legal requirements were also noted.

Altogether 186 records of 92 male and 94 female patients were used in the study. Their ages varied between a baby of three months to an elderly of 87 years. A wide variety of operations were performed on the selected patients (see Figure $1)$. operative assessments can be made. This time was not recorded in $3.7 \%$ of the records, which means that base-line information was missing.

The vital signs of $80.6 \%$ of the patients were monitored within a quarter of an hour of their return to the ward, $10.2 \%$ within half an hour, $3.2 \%$ within one hour and $1.6 \%$ between one and three hours. In $3.7 \%$ of the records there was no indication of when the patient returned from the theatre and no deduction could be made about how soon afterwards their vital signs were monitored for the first time.

\section{Neurological status}

The neurological status of most of the patients, that is, $81.7 \%$, was assessed on their return to the ward from the theatre. In

\section{Table 1: Descriptions of neurological status}

\begin{tabular}{|c|c|c|c|}
\hline No. & DESCRIPTION & $\mathbf{N}$ & $\%$ \\
\hline 1 & Awake & 66 & 43.4 \\
\hline 2 & $\begin{array}{cc}\text { Awake with a further qualification, e.g.: } \\
\text { - Awake and tearful } \\
\text { Awake in pain/no pain } \\
-\quad \text { Awake and satisfactory } \\
-\quad \text { Awake and reacts well } \\
\text { Awake with pain and nausea } \\
-\quad \text { Awake and } \\
\text { orientated/disorientated } \\
-\quad \text { Awake and crying } \\
\end{array}$ & 41 & 27.0 \\
\hline 3 & Asleep, sleepy, drowsy & 19 & 12.5 \\
\hline 4 & $\begin{array}{l}\text { Drowsy but responds to pain } \\
\text { stimuli/instructions }\end{array}$ & 8 & 5.3 \\
\hline 5 & Crying/tearful & 8 & 5.3 \\
\hline 6 & Pain/no pain & 4 & 2.6 \\
\hline 7 & Restless & 3 & 2.0 \\
\hline 8 & No feeling in limbs & 2 & 1.3 \\
\hline 9 & Orientated & 1 & 0.7 \\
\hline
\end{tabular}

\section{Time of return to the ward and commencement of postoperative assessment}

The time a patient is received from theatre is regarded as an important step in postoperative management and whether this was recorded was noted on the checklist. This information provides the basis from which to work so that accurate post- these cases the nurse paid most attention to the patient's level of consciousness, which is the most important neurological parameter.

The descriptions of neurological status used, with their frequencies, are given in Table 1.

\section{Emotional status}

The emotional status of only $25.9 \%$ of all respondents was assessed. In these cases the description given was very vague 
and the researchers had to assume that if a patient was asleep, he was calm.

\section{Physical comfort}

Very little attention was given in the records to the physical comfort the patients experienced. Physical comfort was mentioned in only $8.1 \%$ of the records.

\section{Respiratory and circulatory status \\ Vital signs}

In most cases the vital signs were monitored, but not at the prescribed frequency. Respirations were monitored in $94.6 \%$ of cases, blood pressure in $88.7 \%$, pulse rate in $96.8 \%$ and body temperature in $93 \%$ of the cases. A possible explanation for the slightly lower percentage of blood pressure monitoring is that $17.2 \%$ of the records used were those of children under 12 years, and their blood pressure is measured only in exceptional cases.

The frequency of monitoring is illustrated in Table 2

Vital signs were very poorly followed up when a reading was abnormal. This trend is reflected in Table 3. logical agents that were administered was complete, but less attention was given to follow-up actions in the management of pain.

Although whether or not the patient had pain was mentioned in $71.5 \%$ of the cases, a pharmacological agent was administered in $73 \%$ of cases. In only $19 \%$ of cases was the effect of the drug written down within an hour.

Table 4 shows the completeness of the records of pharmacological agents administered.

In $80 \%$ of cases where the fact that the drug was not effective was recorded, an alternative drug was administered.

\section{Fluid balance}

\section{Intravenous fluid therapy}

In general the intravenous intakes were poorly monitored and in only $45.2 \%$ of the $89.2 \%$ of respondents who had an infusion in situ on retum to the ward, was there an indication of the amount of fluid left in the vacolitre. It was only in these cases that the nurse had a basis from which to work.

\section{Elimination}

Elimination in the first eight postoperative hours was poorly

\section{Table 2: Frequency of monitoring of vital signs as measured against the prescribed guidelines for monitoring}

\begin{tabular}{|c|c|c|c|c|c|c|c|}
\hline \multicolumn{2}{|c|}{ VITAL SIGNS } & \multicolumn{2}{|c|}{$\begin{array}{c}\text { 4X } \\
\text { FIRST } \\
\text { HOUR }\end{array}$} & \multicolumn{2}{|c|}{$\begin{array}{c}2 X \\
\text { SECOND } \\
\text { HOUR }\end{array}$} & \multicolumn{2}{|c|}{$\begin{array}{l}\text { HOURLY } \\
\text { FOR NEXT } \\
4 \text { HOURS }\end{array}$} \\
\hline & & $\mathbf{N}$ & $\%$ & $\mathbf{N}$ & $\%$ & $\mathbf{N}$ & $\%$ \\
\hline \multirow[t]{2}{*}{ Respiration } & Yes & 44 & 25 & 37 & 21 & 18 & 10.2 \\
\hline & No & 132 & 57 & 139 & 79 & 158 & 89.8 \\
\hline \multirow[t]{2}{*}{ Blood pressure } & Yes & 38 & 23 & 34 & 20.6 & 16 & 9.7 \\
\hline & No & 127 & 77 & 131 & 79.4 & 149 & 90.3 \\
\hline \multirow[t]{2}{*}{ Pulse rate } & Yes & 43 & 23.9 & 36 & 20 & 17 & 9.4 \\
\hline & No & 137 & 76.1 & 144 & 80 & 163 & 90.6 \\
\hline \multirow[t]{2}{*}{ Temperature } & Yes & 42 & 24.3 & 36 & 20.8 & 17 & 9.8 \\
\hline & No & 131 & 75.7 & 137 & 79.2 & 156 & 90.2 \\
\hline
\end{tabular}

\section{Capillary refill}

Monitoring capillary refill was absolutely essential in $11.9 \%$ of the cases, but only $3.8 \%$ of those case were monitored. No evaluation of the follow-up actions could therefore be made if the capillary refill was abnormal.

\section{The management of postoperative pain}

In most cases the postoperative pain experience of the patient was monitored and in most cases the recording of pharmaco monitored. In $29.6 \%$ of the records there was no indication whether or not the patient had a catheter in situ. Of the $28.5 \%$ for whom a urinary catheter was indicated, the amount of urine in the bag on return to the ward was recorded in only $30.2 \%$ of cases.

In only $30 \%$ of cases was the first urine the patient passed postoperatively mentioned. In only $3.2 \%$ of cases was bladder fullness and in $2.7 \%$ cases urinary retention mentioned. 


\section{Drainage tubes}

Drainage tubes were generally poorly monitored. Of the $17.3 \%$ of patients who had drainage tubes in situ, only $43.8 \%$ had the amount of drained fluid recorded.

\section{Haemorrhage}

The patients were well monitored for external bleeding, but were completely illegible, which could lead to faulty interpretation and therefore legal implications.

\section{Signatures and ranks}

Only $22.6 \%$ of the nurses' signatures were legible and in only $67.7 \%$ of the records did they add their rank to each signature.

Table 3: Follow-up of abnormal vital signs

\begin{tabular}{|l|c|c|c|c|}
\hline \multicolumn{1}{|c|}{ VITAL SIGNS } & \multicolumn{2}{c|}{$\begin{array}{c}\text { ABNORMAL } \\
\text { READINGS }\end{array}$} & \multicolumn{2}{c|}{$\begin{array}{c}\text { FOLLOW-UP } \\
\text { NURSING } \\
\text { ACTIONS }\end{array}$} \\
\cline { 2 - 5 } & N & $\%$ & N & $\%$ \\
\hline Respiration & 1 & 0.6 & 0 & 0 \\
\hline Blood pressure & 31 & 18.8 & 4 & 12.9 \\
\hline Pulse rate & 12 & 6.7 & 3 & 25 \\
\hline Temperature & 6 & 3.5 & 3 & 50 \\
\hline
\end{tabular}

Table 4: Completeness of recording of pharmacological agents administered

\begin{tabular}{|c|c|c|c|c|}
\hline \multirow{2}{*}{ ASPECT } & \multicolumn{2}{|c|}{ YES } & \multicolumn{2}{c|}{ NO } \\
\cline { 2 - 5 } & $\mathbf{N}$ & $\%$ & $\mathbf{N}$ & $\%$ \\
\hline Time of administration & 136 & 100 & 0 & 0 \\
\hline Type of analgesic administered & 132 & 97.1 & 4 & 2.9 \\
\hline Dose administered & 132 & 97.1 & 4 & 2.9 \\
\hline Site/route of administration & 97 & 71.3 & 39 & 28.7 \\
\hline Effect within an hour of administration recorded & 27 & 19.9 & 109 & 80.1 \\
\hline
\end{tabular}

only once on return from the theatre. For instance, in only $31.2 \%$ of cases were the wound dressings checked more than once.

\section{Description of surgical intervention}

Generally speaking the type of surgical intervention performed was indicated in the records.

\section{Legibility and record-keeping}

\section{Handwritings}

The handwritings of the nurses were legible in most cases (70.3\%). However, $27.1 \%$ were read with difficulty while $2.6 \%$

\section{Completeness of records}

The records were mainly complete regarding:

signature after each entry;

date at the top of each page;

patient's name and number on each page;

page number on each page; and

the time at each entry. 


\section{Conclusions and recommendations}

The main findings of this research study were:

- Neurological status: The neurological status of the majority of patients was assessed on return to the ward from the theatre. The nurses' main concern was the patient's level of consciousness.

Emotional status: Very few patients had their emotional condition assessed and if it was done the description was very vague.

Physical comfort: Little attention was paid in the records to the physical comfort of the patient. In only a few cases was the fact mentioned that the patient was placed in a therapeutic position for comfort.

Respiratory and circulatory status: Vital signs were monitored but in most cases not at the prescribed frequency. In general the vital signs were best monitored at the prescribed frequencies in the first hour postoperatively. The frequency of monitoring in the second hour postoperatively deviated further from the prescriptions and from the third to the seventh hour few of the records met the prescribed frequencies. Respirations were monitored best, followed by body temperature and then blood pressure and/or pulse rate. Capillary refill was also poorly monitored.

Management of postoperative pain: In most cases the postoperative patient's pain experience was monitored. Most of the records of pharmacological agents administered were also complete, although nurses were inclined to omit the site or route of administration. Litthe attention was paid to follow-up actions in the management of pain.

Fluid balance: Intravenous intake was inadequately monitored in most cases, as was the patient's urinary output in the first eight hours postoperatively. Little attention was paid to bladder fullness and urine retention. Generally speaking drainage tubes were poorly checked and the amount and nature of the drainage was not always indicated. The patients were well monitored for signs of external bleeding but in most cases it was checked only once on return from the theatre.

Description of the surgical intervention: In most cases the type of surgical intervention performed was indicated in the nursing records. Less attention was given to the type of anaesthetic used. Where it applied, the type of suturing material was seldom mentioned. The specific location of the surgical intervention was not always indicated when necessary. handwritings were legible in most cases but their sig natures and ranks were illegible. Record-keeping was mainly complete regarding a signature at each entry, date at the top of each page, the patient's name and number on each page, page number on each page and time of each entry.

- $\quad$ Allergies: In most cases the patient's allergies were entered in the theatre preparation report and admission report and to a lesser extent in the progress report.

The parameters that were adequately recorded were therefore neurological status, the patients' pain experience, haemorrhage and allergies. Record-keeping was generally complete and most of the records were legible but the signatures and ranks of the nurses were illegible. The patients' emotional status, physical comfort, respiratory and circulatory status, follow-up actions after administration of pharmacological agents and fluid balance were inadequately recorded. In these cases the documents did not meet legal requirements.

\section{Recommendations Utilisation of a postoperative documentation form}

The fact that there are many factors that influence the quality and recording of nursing care must be borne in mind. Not only do the knowledge and preciseness of the nursing staff play a role, but factors that have an emotional impact also influence their work. Examples include working conditions, job satisfaction, workload, staff reduction and available facilities (Shindul-Rothschild, Long-Middleton \& Berry, 1997:35-43).

It is for this reason that Palmerini (1996:239-240) recommends the use of a comprehensive and easily usable documentation form for postoperative nursing care. Such a form would act as a checklist and would ensure to a great extent that attention is paid to the most important postoperative parameters.

From a legal point of view a comprehensive form that provides for a checklist with room for descriptive notes would reduce the potential for patient injury and neglect. It would also reduce the potential for legal problems as it would lead the nurse through the most important patient care actions.

As a consequence of the literature review they conducted and the insights they gained from the evaluation of patient records, the researchers compiled the postoperative documentation form depicted in Figure 2.

\section{Improvement of legibility}

Greater awareness of clear and legible handwriting and signatures must be cultivated, especially in view of the fact that patient records are legal documents. Handwritings that are difficult to read or illegible can cause interpretation errors that could harm the patient. The researchers recommend that nurses with unclear signatures print their names below their signatures. One of the wards evaluated implemented this custom and it enhanced the legal quality of the records and cre- 


\section{More complete assessment of neurological status}

As indicated, the patients' neurological status was monitored in most cases. However, the descriptions were vague and the researchers recommend that, as stated by Viljoen and Uys (1993:386-387), nurses assess and record patients' neurological status in terms of the following three aspects:

- Level of consciousness and orientation

- Sensory function

\section{Recording the patient's allergies}

In one of the wards where patient records were evaluated the patients' allergies were entered on the care plan in addition to the admission report, progress report and theatre preparation report. As the care plan is usually placed first in the patient file and is read at every handing over of report, this is a logical place to enter the patient's allergies.

The recommendation in this case is that patients' allergies be

\section{Figure 2: Postoperative documentation form}

\section{POSTOPERATIVE NURSING CARE}

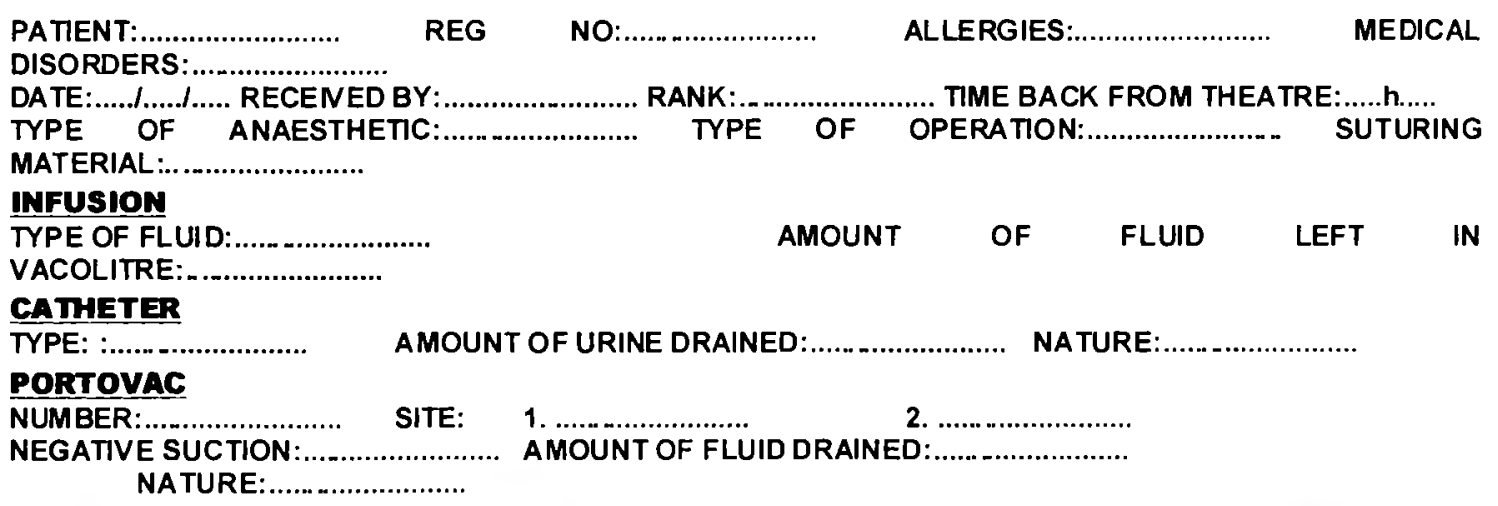

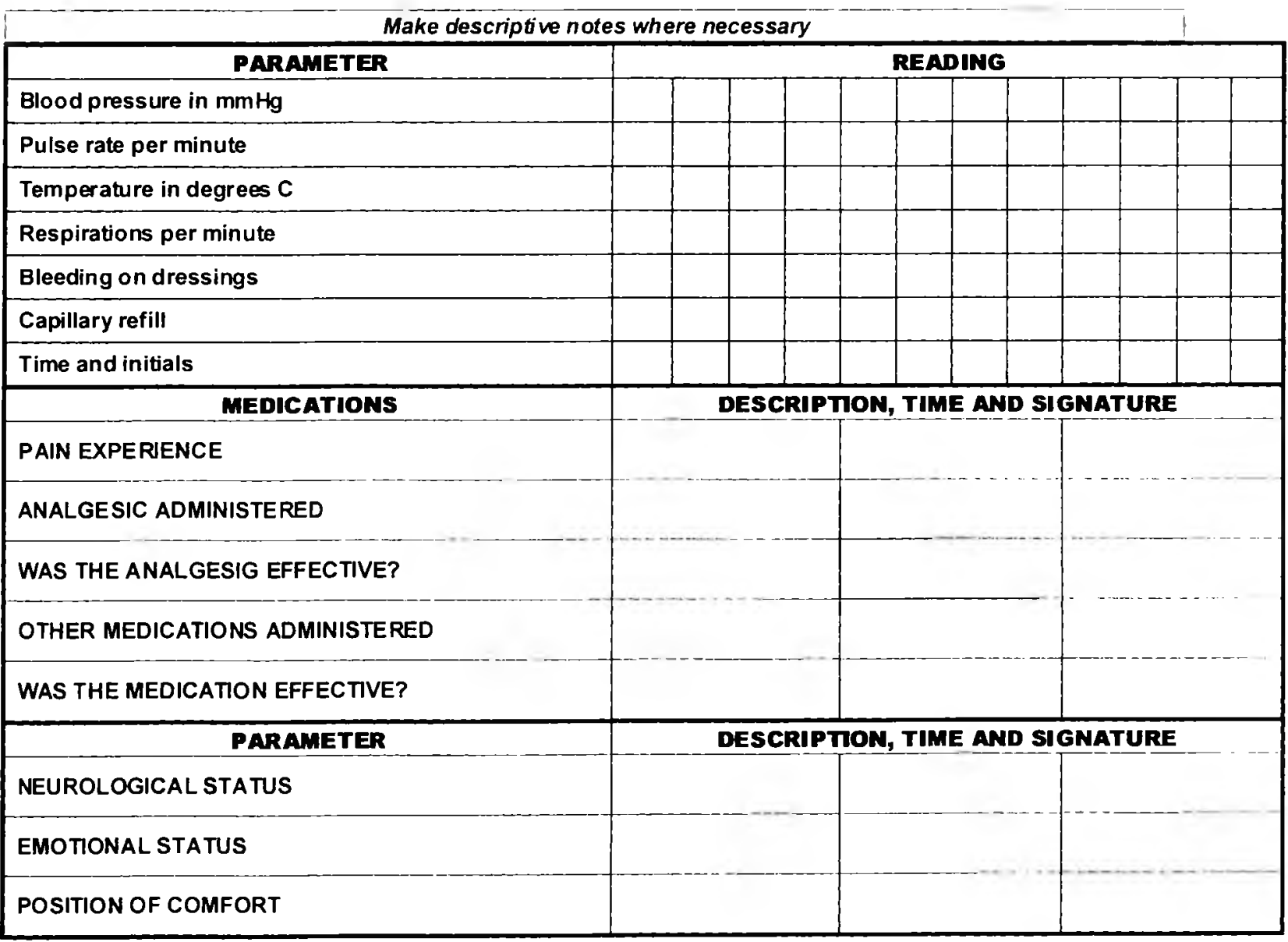




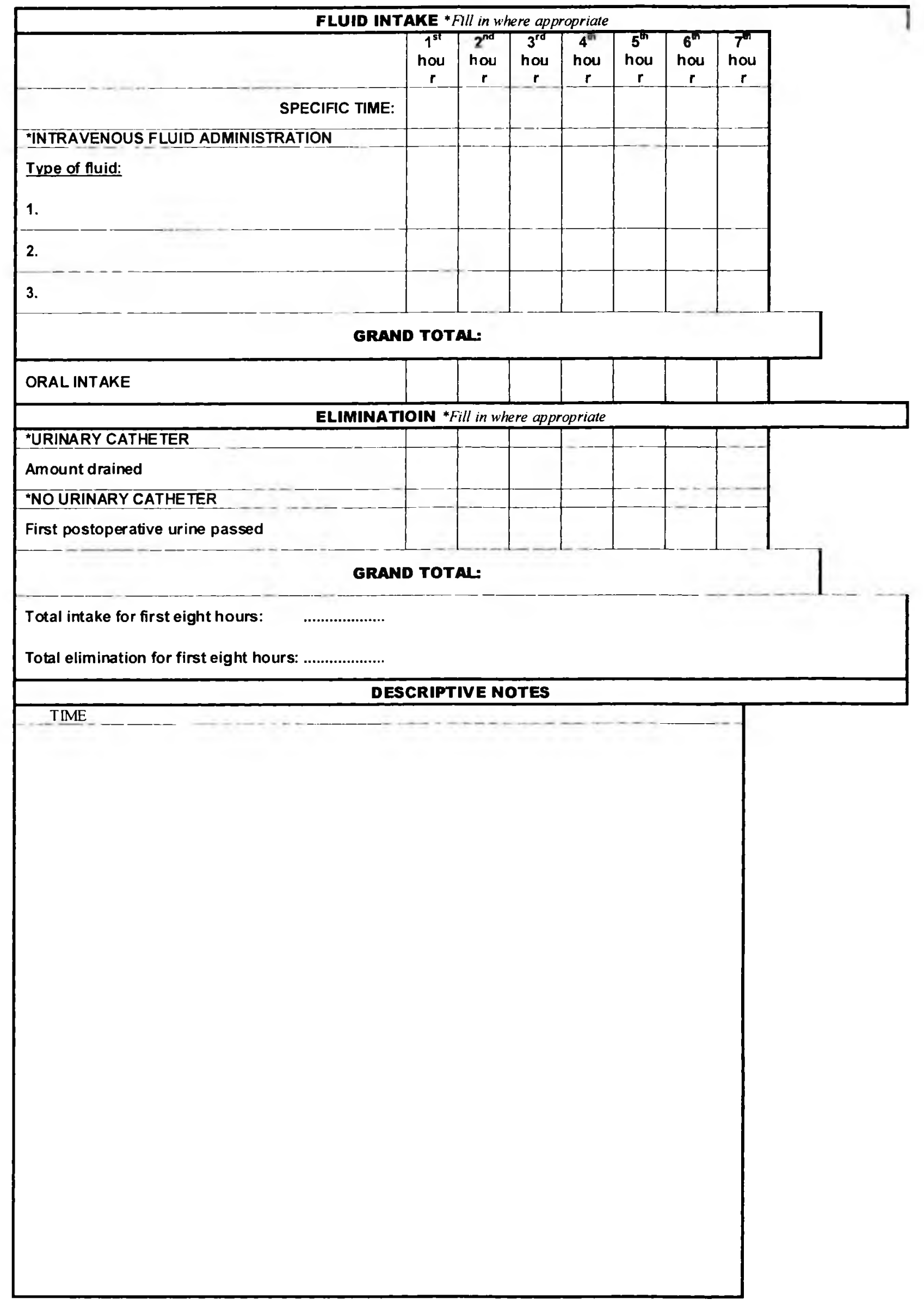


entered on every page of the progress report together with their name and number. If this is done throughout and accurately it will serve as an easy point of reference for nurses when they need to administer a pharmacological agent.

\section{Summary}

The postoperative parameters that were adequately addressed were neurological status, monitoring the patients' experience of pain, haemorrhage and keeping record of their allergies. In most cases recording was complete and most records were legible, but the signatures and ranks were illegible. Parameters that were inadequately recorded were the patients' emotional status, physical comfort, respiratory and circulatory status, follow-up actions after the administration of pharmacological agents and fluid balance.

A comprehensive and easily usable documentation form should therefore be used in postoperative nursing care.

\section{References}

BRESLOW, MJ; MILLER, CF \& ROGERS, M 1990: Preoperative management. St. Louis: The C.V. Mosby Co.

BURNS, N \& GROVE, SK 2001: The practice of nursing research. Philadelphia: W.B. Saunders.

CHAPPEL, T 1997: Quality control of patient care records. Nursing News. Nov., 21(11):50-52.

HERBST, MC (Ed) 1997: The golden rule: If you did not record it, you did not do it! Nursing News, 21(10):39-41.

KAEMPF, G \& GORALSKI, VJ 1996: Monitoring postoperative patients. Registered Nurse. July, 59(7):30-35.

NEUMAN, WL 1997: Social research methods: Qualitative and quantitative approaches. Boston: Allyn and Bacon.

PALMERINI, J 1996: Developing a comprehensive perioperative nursing documentation form. AORN Journal, 63(1):239-247.

PHIPPS, WJ, LONG, BC, WOODS, NF \& CASSMEYER, VL (Reds) 1999: Medical-surgical nursing: Concepts and clinical practice. $6^{\text {th }}$ ed. St. Louis: C.V. Mosby.

POLLOCK, AV 1991: Postoperative complications in surgery. Oxford: Blackwell Scientific Publications.

SHINDUL-ROTHSCHILD, J, LONG-MIDDLETON, E \& BERRY, D 1997: 10 Keys to quality care. American Journal of Nursing. 97(11):35-43.

SUDDARTH, DS 1994: The Lippincott manual of nursing practice. $5^{\text {th }}$ ed. Philadelphia: J.B. Lippincott.

VAN DER MERWE, WL \& SHIPTON, EA 1990: Postoperatiewe pynverligting. VMO/CME, 8(12):1221-1226.
VILJOEN, MJ \& UYS, LR (Reds) 1993: Algemene verpleegkunde: Mediese en chirurgiese handleiding. Pretoria: HAUM.

VERSCHOOR, T, FICK, GH, JANSEN, RM \& VILIJOEN, DJ 1996: Verpleegkunde en die reg. Kenwyn: Juta \& Kie Beperk. 